\title{
Development of Distance Education Attitude Scale for Teachers: A Study of Validity and Reliability
}

\author{
Serpil Deniz \\ Ministry of Education, Gaziantep, TURKEY \\ Birsen Bağçeci \\ Gaziantep University, Faculty of Education, TURKEY
}

Received: 18 August 2021 - Accepted: 19 October 2021 • Published Online: 8 November 2021

\begin{abstract}
The purpose of this study is to examine the validity and reliability of the Distance Education Attitude Scale for Teachers, which was developed to reveal teachers' attitudes towards distance education during the COVID-19 outbreak. Statistical analyses were performed on 458 of the collected forms. The study group was randomly divided into two and the EFA process was conducted with 205 participants and the CFA process with 253 participants. KMO and Bartlett tests were performed to determine the suitability of the data for EFA. The KMO value was 0.0885 and the Bartlett test was statistically significant $\left(\chi_{2}=3141, \mathrm{df}=703, \mathrm{p}<0.001\right)$. EFA results show that the DEASFT structure consists of 21 items and two factors, and these factors are named as "Benefits of Distance Education" and "Limitations of Distance Education". CFA was applied on the data of 253 different people to the factor structures obtained as a result of AFA Analyses. One item was dropped from the scale because p values (0.178) is bigger than 0.05. According to fit indices $\left(\chi^{2} / \mathrm{df}<1.5, \mathrm{CFI}=0.953>0.9, \mathrm{TLI}=0.942>0.9, \mathrm{SRMR}=0.0735<0.8, \mathrm{RMSEA}=0.0427\right.$ $<0.05$ ), the scale is validated. The final version of scale has two factors and 20 items. Cronbach Alpha and composite reliability coefficients were calculated for reliability. For factor 1 Cronbach $\alpha=0.847$ and McDonald's $\omega=0.836$. For factor 2 Cronbach $\alpha=0.815$ and McDonald's $\omega=0.845$. The results of the analysis show that the scale is a valid and reliable measurement tool for determining teachers' attitudes towards distance education.
\end{abstract}

Keywords: distance education, scale development, teachers' attitudes.

\section{Introduction}

The COVID-19 epidemic, which causes sudden and unpredictable changes globally in very serious dimensions, has led to problems in all countries in social, economic, psychological and many other areas. Even if it is called "the new normal", this epidemic, which causes the whole world to experience abnormal times and seriously changes the daily routine of people, has brought many necessary changes. Although the rhythm of the COVID-19 epidemic, which began in December 2019, has changed from time to time, it has shown its most devastating effect in the health sector and then in the education sector (Yamamoto \& Altun, 2020). The epidemic, which cannot be controlled, has stopped the flow of life worldwide, caused millions of schools to be closed indefinitely and brought the education system of countries to a halt (Zhao, 2020). Strict

(C) Authors. Terms and conditions of Creative Commons Attribution 4.0 International (CC BY 4.0) apply. Correspondence: Serpil Deniz, Ministry of Education, Gaziantep, TURKEY. E-mail: 
prohibitions such as curfews, travel restrictions, and the closure of social places where people come together to prevent the COVID-19 epidemic have been implemented in most countries. But the most serious and drastic measures have shown themselves in the field of education. During the mandatory isolation process, schools were closed in 191 countries at all levels around the world, and the educational life of about 1.6 billion students was disrupted (UNESCO, 2020). With 90\% of the students in the world staying away from school and being closed to home, the serious deficiency in education caused by the epidemic has mobilized all countries of the world. In order to minimize the negative impact of the epidemic on all educational stages from first grade to higher education, each country has created strategies within its own capabilities, changed its educational policies and had to develop urgent practices (Belay, 2020; Fernando \& Schleicher, 2020). For the purpose of avoiding further interruption of Education, various distance education activities have started to be used in all countries of the world (Yamamoto \& Altun, 2020). Different tools, assignments, updated and structured contents and alternative training models were used in these programs to continue the interrupted training (Zhao, 2020). The increasing threat of the epidemic has required countries to take urgent decisions to prevent learning losses while trying to protect their students, teachers and staff from the virus (Hodges at al., 2020).

Although many experts have argued about the negative effects of distance education such as unhealthy graduates (Lau, Yang \& Dasgupta, 2020) and changing in assessment (Cahapay, 2020), technical problems will reduce the effectiveness and efficiency of education (Anderson \& Dron, 2011), students who are distant to technology will spend time on the use of educational tools rather than the course itself (Miltiadou \& Yu, 1999), or the communication barriers between students and teachers that may occur during the course (Perreault et al., 2002), due to curfews and closed schools, distance education has become not an option but an obligation all over the world (Yamamoto \& Altun, 2020).

Distance education programs, which have been used for many years especially in higher education throughout the world and in Turkey, have become a mandatory situation for students and teachers studying at all levels, from primary schools to universities with the outbreak of COVID-19 (Durak et al., 2020). This situation has radically changed the educational life not only for students who have been educated face-to-face for years, but also for teachers (Lall \& Singh, 2020). These major changes have also raised concerns such as access inequality, communication problems, technical difficulties, increased workload and stress, difficulty assessing student participation, and poor work-life balance (Abu Talib et al., 2021). From the point of view of students and teachers, the idea emerged that education is not exactly the same as classical distance education, due to a lack of time and resources in accessing information about distance education, lack of necessary equipment and technological infrastructure, and the presence of negative psychological factors caused by the epidemic (Ylldırım, 2020). In various national and international sources, the new education process and the applied distance education model that emerged with the COVID-19 crisis have been described as "Emergency Remote Education" (Affouneh et al., 2020; Bozkurt \& Sharma, 2020a; Hodges et al., 2020). This new definition has been described as an exceptional situation that cannot be considered as normal education for teachers, students and parents in the shadow of the epidemic (Aguliera \& Nightengale-Lee, 2020; Milman, 2020). It has been emphasized in many sources that emergency distance education is different from known distance education. Emergency remote education includes not only physical distance, but also the concepts of interactional and psychological distance, is unplanned, is created quickly to be applied in the crisis process, is applied temporarily, brings problems such as technological infrastructure, participation, economic situation experienced by learners and teachers, and arises from necessity, not preference (Bozkurt, 2020; Bozkurt \& Sharma, 2020b; Carter et al., 2020; Hodges at al., 2020).

According to the report of the Ministry of Education of Turkey (2019) with the outbreak of COVID-19, education was the most affected institution by the crisis with about 18 
million students and 950 thousand teachers (Bakioğlu \& Çevik, 2020). November 23 March 2020 in Turkey, the emergency distance education model first started to be implemented through 3 television channels and Educational Information Network (EBA) connected to TRT, the process continued with live lessons as it progressed, and from November it was decided to continue all official, private, formal and widespread educational activities through distance education. Considering that the transition to emergency distance education takes place quickly and unprepared, it cannot be said that teachers, students and parents are psychologically fully prepared for their technological and physical infrastructure needs. As a matter of fact, research has shown that students and teachers are weak in terms of digital skills and technological support needed to pass the distance education process effectively and efficiently (Alipio, 2020; Bozkurt, 2020; Başaran et al., 2020). However, it is known that in the epidemic process, the issue is not only technical, but also many pedagogical difficulties (Ali, 2020). It is also important that students and teachers have a positive perception of the program as well as having the necessary technological infrastructure and the knowledge and skills required by education for the successful and healthy implementation of distance education. Because it is important that this sudden digital transformation with the epidemic occurs simultaneously with not only a technological transformation, but rather a mental transformation (Bozkurt, 2020). In affective characteristics that are important for learning, the individual's attitudes have a great influence (Erden, 1995; Gardner, 1985; Tavşancll, 2005), studies have revealed that attitude affects learning in virtual environments where distance education is carried out (Sanders \& Morrison-Shetlar, 2001).

For a successful distance education application; considering that teachers' perceptions are of great importance (Tzivinikou et al., 2020), the attitude of the individual towards his / her job affects job performance (Kahramanoğlu et al., 2018), and teachers' attitudes are also reflected in students (Aydın \& Sağlam, 2012), it is important to determine and evaluate teachers' attitudes towards distance education during the emergency distance education process. Teachers' interest in distance education, their thoughts and feelings about the program, and how they evaluate distance education greatly affect the implementation process of the program. It is known that successful distance education can only be achieved with teachers who can provide quality education (Tabata \& Johnsrud, 2008) and individual beliefs about knowledge, learning and teaching are interconnected (Bay et al., 2015). For all these reasons, it has become a need to determine teachers' attitudes towards distance education, who have an important role as the practitioner of the program.

There are many studies that examine attitudes towards distance education in national and international fields. But most of the work done in Turkey has been done with students or academics in higher education (Eygü \& Kahraman, 2013; Kışla, 2016; Arslan, et al., 2019; Çelik \& Uzunboylu, 2020). A glimpse of research literature reveals that a little research studies on attitudes towards distance education have been carried out on primary, secondary and high school teachers working within the Ministry of education in Turkey (Ağır, 2007; Ayyldız et al., 2006). None of the studies have been carried out in order to evaluate the perceptions of teachers for emergency distance education, which is enforced by teachers at all levels during a crisis like COVID-19, their preparation for distance teaching, the problems and needs they face in their teaching processes. It is necessary to analyze the current situation first in order to determine the functioning of the applied emergency distance education program, the problems experienced, the needs and the solution proposals. Determining the attitudes of teachers who are the practitioners of emergency distance education is of great importance in terms of conducting studies to reduce their existing negative attitudes, bringing to light the problems brought by the program and helping to solve them. This study was carried out in order to develop a valid and reliable scale to determine the attitudes of teachers working in schools affiliated to the Ministry of Education in Turkey and switching to urgent distance education within the scope of measures taken during the COVID-19 epidemic. 


\section{Methodology}

This study is a valid and reliable scale development study to determine the attitudes of teachers towards immediate distance education implemented during the COVID-19 epidemic. This scale development study was carried out in the fall semester of the 2020-2021 academic year in Turkey.

\subsection{Sample}

The study's working group consists of 502 teachers working in private or public schools in the Ministry of National Education of Turkey. After the missing forms were eliminated, the remaining 458 data were analyzed. In scale development studies, the number of sample groups is important for validity and reliability studies. As well as the size of the sample, it is also important that it is diverse to represent the target audience (Tezbaşaran, 2008). It is stated in the literature that the number of participants should be five or ten times the number of items in the scale (Child, 2006; Nunnally, 1978). However, Nunnally (1978) found that a sample group of 300 people was sufficient in scale development studies, Comrey and Lee (1992) stated that 50 people are very poor, 100 people are low, 200 people are medium, 300 people are good, 500 people are very good and 1000 people are a perfect number. In the light of this information, it can be said that the total number of 458 participants in the study is a good number for the scale development study. The demographic variables of the study group are given in Table 1.

Table 1. Demographic variables of the sample

\begin{tabular}{llll}
\hline & & Frequencies (f) & Percentage (\%) \\
\hline Gender & Female & 298 & 65.1 \\
& Male & 160 & 34.9 \\
Type of School & Public School & 391 & 85.4 \\
& Private School & 67 & 14.6 \\
Grade & Primary School & 43 & 9.4 \\
& Secondary School & 134 & 29.3 \\
\multirow{2}{*}{ Total } & High School & 281 & 61.4 \\
\hline
\end{tabular}

The study group of the research consists of a total of 458 teachers, 298 (65.1\%) females and 160 (34.9\%) males. 391 of the teachers in the study group are in public school and 67 are in private school; 43 of them are teachers working in primary school, 134 in middle school, 281 in high school.

\subsection{Development process of attitude scale}

This scale development work consists of five stages.

In the first stage; In order to determine the items of the distance education attitude scale and how to develop the attitude scale, national and international attitude scale studies towards distance education have been carefully examined (Çelik \& Uzunboylu, 2020; Kışla, 2016; Eygü \& Kahraman, 2013; Ayyıldız, at al., 2011; Tzivikov, at al., 2020; Kumari \& Sood, 2018; Mahmoud Raba, 2013). In addition, written answers were obtained from 92 teachers by using a form consisting of open-ended questions prepared online in order to learn teachers' opinions and feelings about distance education. After reviewing the relevant literature and analyzing the teachers' opinions, an item pool of 46 items consisting of half positive and negative statements was created. 
In the second stage; In order to ensure the validity of the content of the scale, the opinions of 4 experts in the field were consulted and they were asked to evaluate the clarity of the structure, the level of interest, the accuracy, the excess of the structure and the "suitability" of the structure. According to the feedbacks of the experts, after calculating the A-CVI and UA for each item, 8 items were removed from the scale and some items were edited (Yusoff, 2019; Polit, 2007).

In the third stage; The scale items were examined with a language expert in terms of spelling, grammar rules and expression disorders and re-evaluated individually. The scale was applied to 12 teachers in order to evaluate its intelligibility and no changes were made since there were no items that were not understood by the teachers. The prepared draft form is designed as a Likert type scale with 5 options. The degrees included in the scale are 1 (strongly disagree), 2 (strongly disagree), 3 (ambivalent), 4 (agree), 5 (strongly agree). As a result of the regulations, a draft form consisting of 20 negative and 18 positive items was obtained.

In the fourth stage; The final draft of the 38-item attitude scale was applied to 502 teachers to calculate the validity and reliability of the attitude scale. A total of 502 teachers working in private or public schools under the Ministry of Education of Turkey, in different schools, at different levels and in various branches, were applied online. After the missing forms were eliminated, the remaining 458 data were analyzed.

In the last stage; Jamovi (1.6.9) software was used in descriptive and deductive analyses at the stage of psychometric properties of the scale in the study. In scale development studies, it was emphasized that performing EFA and CFA studies with different groups would yield more effective results (Fabrigar at al., 1999; Worthington \& Whittaker, 2006). In this scale development study, the 458-person study group was randomly divided into two, and Exploratory Factor Analysis (EFA) studies were conducted with 205 participants and Confirmatory Factor Analysis (CFA) studies with 253 participants. The validity and reliability analysis were carried out with the whole study group. Before conducting factor analysis, factorability was studied, which determines whether the data collected is sufficient to develop factors. The Kaiser-Meyer-Olkin Measure of Sampling Adequacy (KMO) and Barlett's test was checked. The KMO value varies between $\mathrm{o}$ and 1. An index above 0.50 suggests factor analysis (Williams, Brown \& Onsman, 2010). First, the Kaiser-Mayer-Olkin (KMO) and Bartlett's Test were performed to determine the suitability of the data for factor analysis. Exploratory Factor Analysis (EFA) and Confirmatory Factor Analysis (CFA) were applied to the scale, which is suitable for factor analysis. AFA is a multivariate statistical method that allows the researcher to create an accurate map of the factors and structures associated with the events studied (Edwards \& Bagozzi, 2000; Watkins, 2018). Exploratory Factor Analysis, as factor rotation method, varimax with Kaiser normalization was used.

During scale development and validation, CFA is conducted to improve items while examining the nature and relationships of structures. Since the structural model is created with DFA, a definitive hypothesis can be created about the cases being studied (Jackson, Gillaspy \& Purc-Stephenson, 2009). Confirmatory factor analysis was applied to examine the goodness of fit and construct validity of the 2-factor scale, which was formed as a result of the exploratory factor analysis applied to the scale. While performing CFA, indices such as Chi-square goodness of fit test, goodness of fit index (GFI), adjusted goodness of fit (AGFI), comparative fit index (CFI), normed fit index (NFI), standardized root mean square (SRMR) were analyzed and root mean square error of approximation (RMSEA) has been calculated. Secondly, Cronbach Alpha coefficient analysis and composite reliability calculations were performed to determine the reliability of the resulting scale. For a perfect reliability level, alpha values should be above 0.70 (Kline, 2011; Lavrakas, 2008) and should not exceed 0.94 (Taber, 2018). 


\section{Findings}

The KMO value of the analysis was .885 , which is considered very good and the Bartlett test was statistically significant $\left(\chi_{2}=3141, \mathrm{df}=703, \mathrm{p}<0.001\right)$. Results of KMO and Barlett's test appear to support the validity of the factor analysis usage for this study. After these analyses, Exploratory Factor Analysis and Confirmatory Factor Analysis were performed on the data obtained from the attitude scale.

\subsection{Exploratory factor analysis of the scale}

Exploratory Factor Analysis, as factor rotation method, varimax with Kaiser normalization was used. The exploratory factor analysis was administered the 38 items. Items with an eigenvalue of 1.00 were retained. In addition, substances (a) loaded into more than one factor, (b) loaded factor is not consistent with the meaning of other substances, and (c) $<0.35$ factor load is obtained substances were deleted (Deng, Wang, Guan \& Wang, 2017; Asgharnezhad, et al., 2020). Eigenvalues and scree plots were examined to determine the number of factors. The results of EFA showed that the scale grouped under 2 factors with eigenvalues larger than 1. Fundamental axis factor analysis and Varimax rotation technique were used to make the factor structures stronger. After using varimax rotation, the factor loadings for each item were examined and loadings of less than 0.40 were eliminated. Since items 6, 8, 14, 21, 27, 30, 34, 35 and 36 had extraction values below 0.40 , they were removed from the scale. Factor analysis was subsequently redone with 29 items. Later, items in multiple dimensions, that is, items with a factor load under both factors were examined. Item 5 with values below the critical value and items 1, 15, 16, 32 and 38 were present under multiple dimensions were also removed from the scale. KMO and Bartlett tests were performed again, as the irrelevant and overlapping materials were cleared. According to the analysis result, KMO value was calculated as 0.872 , Bartlett test result as $\chi^{2}=1379, \mathrm{df}=210$ and $\mathrm{p}<0.001$. The results are very good, and EFA can be tested with data based on the remaining substances. Eigenvalues and scree graphs were examined to determine the number of factors. The results obtained from EFA made over 21 items; The scree graph is given in Figure 1, the eigenvalues table in Table 2, and the variances and total variance of the factors in Table 3.

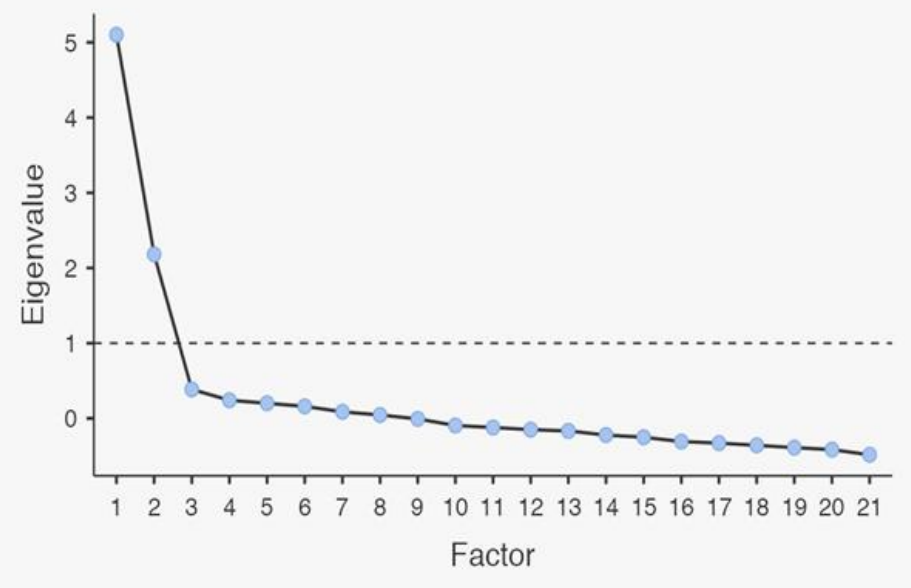

Figure 1. Scree plot of the scale

As can be seen in Figure 1, since there are two eigenvalues greater than 1, a two-factor structure has emerged. 
Table 2. Table of eigenvalues of the scale

\begin{tabular}{|l|r|}
\hline Factors & Eigenvalues \\
\hline 1 & 5.10235 \\
\hline 2 & 2.18130 \\
\hline 3 & 0.38539 \\
\hline 4 & 0.24054 \\
\hline 5 & 0.20098 \\
\hline 6 & 0.15939 \\
\hline 7 & 0.08734 \\
\hline 8 & 0.04447 \\
\hline 9 & -0.00724 \\
\hline 10 & -0.09475 \\
\hline 11 & -0.12163 \\
\hline 12 & -0.15024 \\
\hline 13 & -0.16694 \\
\hline 14 & -0.22197 \\
\hline 15 & -0.25111 \\
\hline 16 & -0.30884 \\
\hline 17 & -0.32866 \\
\hline 18 & -0.35860 \\
\hline 19 & -0.38917 \\
\hline 20 & -0.41538 \\
\hline 21 & -0.48479 \\
\hline
\end{tabular}

When the values in Table 2 were examined, the eigenvalue was calculated as 5.10 in the first factor and 2.18 in the second factor. The scree plot and the eigenvalues table of the scale also support that the scale consists of two factors.

Table 3. The variances and total variances of the factors

\begin{tabular}{|l|r|r|r|}
\hline Factors & Total Load & Percentage of variances & Percentage of Total Variances \\
\hline 1 & 4.04 & 19.2 & 19.4 \\
\hline 2 & 3.52 & 16.8 & 36.0 \\
\hline
\end{tabular}

The scale consisting of 2 factors and 21 items describes $36 \%$ of the total variance when examining the factor structures given in Table 3. According to the correlation calculation between factors, these factors measure different structures. The correlation value is $\mathrm{r}=0.0605$ and is not statistically significant.

Table 4. Factor structures and loadings of the 21 items

\begin{tabular}{|l|l|l|l|l|}
\hline & & & \\
\hline
\end{tabular}


S. Deniz \& B. Bağçeci - Development of Distance Education Attitude Scale for Teachers: ...

\begin{tabular}{|l|l|l|l|l|}
\hline 10 & $\begin{array}{l}\text { I would like to continue distance education when the normal } \\
\text { process starts. }\end{array}$ & 0.553 & 0.596 \\
\hline 19 & I like to research content for use in Distance Education. & 0.552 & & 0.695 \\
\hline 7 & Distance education saves me time and money. & 0.522 & & 0.702 \\
\hline 18 & $\begin{array}{l}\text { It is important for me to reach many students at the same time } \\
\text { with distance education. }\end{array}$ & 0.516 & 0.733 \\
\hline 37 & $\begin{array}{l}\text { I believe that distance education gives students the responsibility } \\
\text { of learning. }\end{array}$ & 0.512 & & 0.687 \\
\hline 13 & $\begin{array}{l}\text { It makes me happy to be able to reach my students, even from a } \\
\text { distance. }\end{array}$ & 0.454 & & 0.791 \\
\hline 4 & $\begin{array}{l}\text { It is easier to provide effective classroom management in distance } \\
\text { education. }\end{array}$ & 0.431 & & 0.741 \\
\hline 11 & $\begin{array}{l}\text { Not getting feedback from students in distance education courses } \\
\text { bothers me. }\end{array}$ & & 0.708 & 0.488 \\
\hline 20 & $\begin{array}{l}\text { I do not like being unable to identify the passive student in } \\
\text { distance education courses }\end{array}$ & 0.657 & 0.566 \\
\hline 9 & $\begin{array}{l}\text { I don't like not being able to communicate one-on-one with } \\
\text { students in distance education lessons. }\end{array}$ & 0.649 & 0.570 \\
\hline 29 & $\begin{array}{l}\text { I am afraid that my students do not understand the subject in } \\
\text { distance education. }\end{array}$ & & 0.590 & 0.625 \\
\hline 12 & $\begin{array}{l}\text { I don't like teaching lessons dependent on the screen. } \\
\text { I think that distance education is not as accepted as face-to-face } \\
\text { education. }\end{array}$ & & 0.583 & 0.519 \\
\hline 3 & I don't like not knowing students in distance education. & & 0.544 & 0.688 \\
\hline 31 & $\begin{array}{l}\text { I am disturbed by the technical problems I experience in distance } \\
\text { education. }\end{array}$ & 0.731 \\
\hline 33 & $\begin{array}{l}\text { The uncertainty of the distance learning process makes it difficult } \\
\text { for me to make a lesson plan. }\end{array}$ & 0.485 & 0.752 \\
\hline
\end{tabular}

As can be seen in the factor analysis results given in Table 4, it was concluded that the items were grouped under two factors, the factor load values were sufficient and each item represents the factor in which it is located. It is observed that the load values of substances vary between 0.431 and 0.708 . As a result of the exploratory factor analysis, 21 items were distributed over 2 factors; factor 1 includes eleven items and factor 2 includes nine items. After the factor analysis, one of the important steps is to measure the common structure of the items collected in the same factor. In the scale we have obtained, items 4, 7, 10, 13, 17, 18, 19, 23, 24, 26, 28, and 37 in the first factor clearly measure teachers' attitudes towards the advantages and contributions of distance education. Therefore; this factor was named as "Benefits of Distance Education (BDE)". The second factor, which consists of 3, 9, 11, 12, 20, 22, 29, 31, and 33 items, measures teachers' attitudes towards disadvantages of distance education, so the second factor is named as "Limitations of Distance Education (LDE)". The items in the scale created were both structurally and semantically consistent.

\subsection{Confirmatory factor analysis of the scale}

When the first model fit indices are examined, it is seen that the CFI and TLI values are above 0.9, the SRMR value is lower than 0.08 and the RMSEA value is less than 0.05. Accordingly, the DFA value of the scale is acceptable. 
Table 5. Model-1 parameter estimates of the scale

\begin{tabular}{|c|c|c|c|c|c|c|}
\hline Factors & Items & Beta & SE & $\mathbf{Z}$ & $\mathbf{p}$ & $\begin{array}{r}\text { Corrected } \\
\text { Item-Total } \\
\text { Correlation }\end{array}$ \\
\hline \multirow[t]{12}{*}{ Factor 1} & 17 & 0.6241 & 0.0703 & 8.88 & $<.001$ & 0.628 \\
\hline & 26 & 0.7573 & 0.0700 & 10.82 & $<.001$ & 0.725 \\
\hline & 23 & 0.5458 & 0.0685 & 7.97 & $<.001$ & 0.577 \\
\hline & 24 & 0.2559 & 0.0578 & 4.43 & $<.001$ & 0.355 \\
\hline & 28 & 0.5768 & 0.0677 & 8.52 & $<.001$ & 0.596 \\
\hline & 10 & 0.6472 & 0.0860 & 7.53 & $<.001$ & 0.546 \\
\hline & 19 & 0.4227 & 0.0641 & 6.59 & $<.001$ & 0.482 \\
\hline & 7 & 0.4331 & 0.0893 & 4.85 & $<.001$ & 0.362 \\
\hline & 18 & 0.5450 & 0.0680 & 8.02 & $<.001$ & 0.588 \\
\hline & 37 & 0.5219 & 0.0778 & 6.71 & $<.001$ & 0.481 \\
\hline & $13^{*}$ & 0.0741 & 0.0551 & 1.35 & 0.178 & 0.111 \\
\hline & 4 & 0.5331 & 0.0842 & 6.33 & $<.001$ & 0.476 \\
\hline \multirow[t]{9}{*}{ Factor 2} & 11_T & 0.5834 & 0.0566 & 10.30 & $<.001$ & 0.666 \\
\hline & $20 \_\mathrm{T}$ & 0.5907 & 0.0694 & 8.51 & $<.001$ & 0.568 \\
\hline & 9_T & 0.6347 & 0.0543 & 11.69 & $<.001$ & 0.755 \\
\hline & 29_T & 0.6976 & 0.0642 & 10.87 & $<.001$ & 0.708 \\
\hline & 12_T & 0.6905 & 0.0652 & 10.60 & $<.001$ & 0.680 \\
\hline & $3 \_\mathrm{T}$ & 0.3780 & 0.0459 & 8.24 & $<.001$ & 0.553 \\
\hline & 31_T & 0.5808 & 0.0658 & 8.83 & $<.001$ & 0.585 \\
\hline & 22_T & 0.4541 & 0.0603 & 7.53 & $<.001$ & 0.527 \\
\hline & 33_T & 0.6074 & 0.0764 & 7.95 & $<.001$ & 0.552 \\
\hline
\end{tabular}

*Not significant at the 0.05 level.

However, since the $\mathrm{Z}$ value between Factor 1 and item 13 was not at a statistically significant level, DFA was repeated by removing 13 . Finally, in the analysis of the 20-item scale, the necessary modifications were made by taking the first analyses into account, and the final result was obtained. The model created for CFA analysis is given in Figure 2.

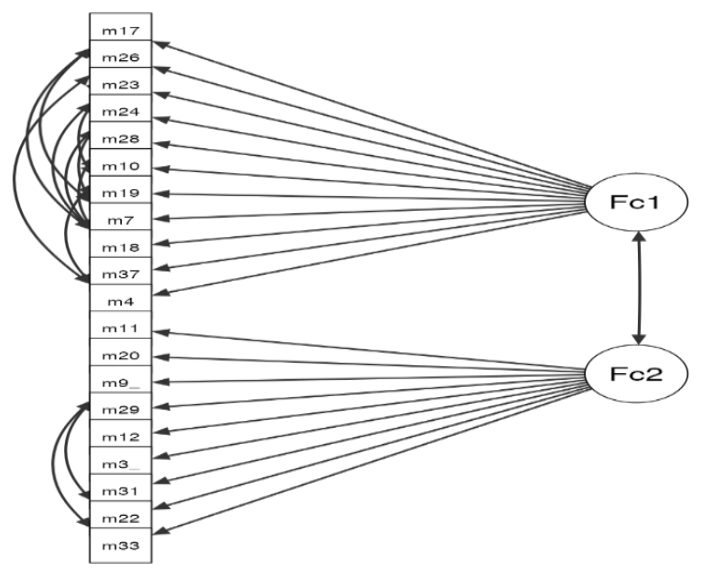

Figure 2. Item factor relationship

Table 6. Fit indices for the models

\begin{tabular}{|l|l|l|l|l|l|l|}
\hline & & & & & \multicolumn{2}{|l|}{ RMSEA 90\% CI } \\
\hline$\chi^{2} /$ df & CFI & TLI & SRMR & RMSEA & Low & High \\
\hline $210 / 152<1.5$ & 0.953 & 0.942 & 0.0735 & 0.0427 & 0.0273 & 0.0562 \\
\hline
\end{tabular}


S. Deniz \& B. Bağçeci - Development of Distance Education Attitude Scale for Teachers: ...

When the model fit indices are examined, it is seen that the CFI and TLI values are above 0.9, the SRMR value is lower than 0.08 and the RMSEA value is less than 0.05. According to these results, it is seen that all fit indices have acceptable values. It can be said that the model is compatible with factors and data when examining fit indices. Based on this, it was concluded that the model and scale items were appropriate.

Table 7. Parameter estimates of the scale

\begin{tabular}{|c|c|c|c|c|c|c|}
\hline Factors & Items & Beta & SE & $\mathbf{Z}$ & $\mathbf{p}$ & $\begin{array}{l}\text { Corrected Item- } \\
\text { Total Correlation }\end{array}$ \\
\hline \multirow[t]{11}{*}{ Factor 1} & 17 & 0.626 & 0.0703 & 8.90 & $<.001$ & 0.630 \\
\hline & 26 & 0.756 & 0.0701 & 10.77 & $<.001$ & 0.723 \\
\hline & 23 & 0.550 & 0.0686 & 8.01 & $<.001$ & 0.580 \\
\hline & 24 & 0.246 & 0.0589 & 4.18 & $<.001$ & 0.342 \\
\hline & 28 & 0.573 & 0.0685 & 8.37 & $<.001$ & 0.592 \\
\hline & 10 & 0.644 & 0.0872 & 7.39 & $<.001$ & 0.544 \\
\hline & 19 & 0.436 & 0.0643 & 6.77 & $<.001$ & 0.497 \\
\hline & 7 & 0.433 & 0.0900 & 4.81 & $<.001$ & 0.362 \\
\hline & 18 & 0.549 & 0.0682 & 8.05 & $<.001$ & 0.591 \\
\hline & 37 & 0.529 & 0.0783 & 6.75 & $<.001$ & 0.488 \\
\hline & 4 & 0.533 & 0.0845 & 6.31 & $<.001$ & 0.476 \\
\hline \multirow[t]{9}{*}{ Factor 2} & 11 & 0.583 & 0.0567 & 10.28 & $<.001$ & 0.665 \\
\hline & 20 & 0.591 & 0.0694 & 8.53 & $<.001$ & 0.568 \\
\hline & 9 & 0.635 & 0.0544 & 11.67 & $<.001$ & 0.755 \\
\hline & 29 & 0.701 & 0.0641 & 10.93 & $<.001$ & 0.712 \\
\hline & 12 & 0.691 & 0.0652 & 10.59 & $<.001$ & 0.680 \\
\hline & 3 & 0.377 & 0.0459 & 8.22 & $<.001$ & 0.552 \\
\hline & 31 & 0.579 & 0.0658 & 8.80 & $<.001$ & 0.584 \\
\hline & 22 & 0.453 & 0.0604 & 7.50 & $<.001$ & 0.525 \\
\hline & 33 & 0.606 & 0.0764 & 7.92 & $<.001$ & 0.551 \\
\hline
\end{tabular}

As seen in Table 6, all $\mathrm{Z}$ values are at a statistically significant level of 0.05 . So, all the items involved are related to the factors. The validity of the 2-factor scale structure revealed by confirmatory factor analysis and exploratory factor analysis was confirmed. Based on all these findings we obtained after the confirmatory factor analysis, it was concluded that the Attitude Scale towards Distance Education is a valid scale.

\subsection{Reliability of the scale}

For reliability calculations, Cronbach Alpha calculations based on EFA sample and also composite reliability (McDonald's $\omega$ ) calculation based on CFA sample analysis was performed. Table 7 summarizes factor names, number of the items and reliability of each factor.

Table 8. Reliability calculations according to scale factors and total scores

\begin{tabular}{|l|l|l|l|}
\hline Factors Name & $\begin{array}{l}\text { Number of } \\
\text { Items }\end{array}$ & Cronbach $\alpha$ & McDonald's $\omega$ \\
\hline Benefits of Distance Education (BDE) & 11 & 0.847 & 0.836 \\
\hline $\begin{array}{l}\text { Limitations of Distance Education } \\
\text { (LDE) }\end{array}$ & 9 & 0.815 & 0.845 \\
\hline Total Scale & 20 & 0.861 & 0.872 \\
\hline
\end{tabular}

According to the results of the analysis, the scale consisted of two factors: the benefits and limitations of distance education. In both reliability calculations, it is considered sufficient to be above 0.7. As seen in table 7, it was determined that Cronbach alpha and McDonald's value of 
each factor is above 0.7. Also, it was found that Cronbach alpha value of total scale is 0.861 and McDonald's value of the total scale is 0.872 . According to these results, it can be said that Distance Education Attitude Scale is a valid and reliable scale.

\section{Discussions and conclusions}

In this study, a reliable and valid scale study was conducted to measure the attitudes of primary, secondary and high school teachers associated with the Ministry of Education in Turkey towards Distance Education during the COVID-19 crisis. The scale created is an easily applicable scale to measure teachers' attitudes towards distance education, which is carried out not only during the epidemic process, but also later for various reasons. It is obvious that distance education models, which became mandatory during the epidemic, made a sudden entrance into the lives of every teacher and student around the world and accelerated the digital transformation in education. It is anticipated that even if schools are opened, distance education practices can partially continue, and will be used as a second option to maintain education in times of regional or national problems. It is believed that the presence of a scale that evaluates teachers' attitudes towards distance education will be very useful for identifying deficiencies in distance education programs and organizing and developing existing programs. It is also believed that positive teacher attitudes will help improve the quality and efficiency of distance education.

When the relevant literature is examined, it is seen that scale studies have been carried out to evaluate the attitudes of especially university students or academicians towards distance education. There has not been enough work on a scale prepared for teachers at all levels for emergency distance education implemented during the COVID-19 outbreak.

The scale of attitude towards distance education was carried out in five stages. After the literature review and evaluation of the opinions of teachers received, an item pool was created. In order to determine the content validity of the measurement tool as a result of the expert evaluations, Item-Content Validity Index (I-CVI), Scale Level-Content Validity Index Average (SCVI/Avg.) And Scale-Content Validity Index Universal Agreement (A-CVI/UA) was analyzed and items not I-CVI=1 were excluded from the scale (Yusoff, 2019). S-CVI/Avg. of the scale 0.967 and A-CVI / UA 0.870, so the results are above the acceptable level (Polit \& Beck, 2006). As a result of expert evaluations, calculations were made for each item and a 38-item draft form of the scale was created. The scale was applied to 458 teachers working at different levels and schools. This number can be considered very good for scale development studies according to various sources (Child, 2006; Nunnally, 1978; Comrey \& Lee, 1992). For the validity and reliability calculations of the scale, EFA and CFA were performed, respectively. As a result of EFA analysis, a two-factor attitude scale consisting of 21 items was obtained. The load values of the items range from 0.431 to 0.708. It has been concluded that the factor load values of items are sufficient and represent the factor in which each item is located. The factors of the scale are named as "Benefits of Distance Education (BDE)" and "Limitations of Distance Education (LDE)". Factors explain 36\% of the total variance. According to the correlation calculation between factors, these factors measure different structures. Examining teacher attitudes regarding the benefits and challenges of distance education is particularly important for the development of programs.

CFA was applied to the factor structures obtained after EFA. An item was removed from the scale because $\mathrm{p}$ values (0.178) were greater than 0.05 . The scale was verified according to calculated fit indices. Looking at the fit indices of the model; Chi-square statistic $(\chi 2 / \mathrm{df})=1.5$ value is less than 3; The RMSEA (0.0427) value is less than 0.06; SRMR (0.0735) value is less than 0.08; The CFI value of 0.953 showed an acceptable fit. After AFA and DFA analyses, a twofactor and 20-point scale was obtained. Cronbach Alpha and composite reliability coefficients were calculated for reliability. Cronbach $\alpha=0.847$ and McDonald's $\omega=0.836$ were found for the first factor and Cronbach $\alpha=0.815$ and McDonald's $\omega=0.845$ were found for the second factor and 
S. Deniz \& B. Bağçeci - Development of Distance Education Attitude Scale for Teachers: ...

these numbers represent a perfect reliability level (Kline, 2011; Lavrakas, 2008; Taber, 2018). While the high Cronbach Alpha internal consistency coefficient (0.861) of the scale shows that the items are consistent with each other, the results of EFA and CFA have also proven the validity of the scale. As a result of the study, considering the validity and reliability calculations, it can be said that the attitude scale towards distance education can be used in studies to determine teachers' attitudes. The attitude scale developed in this study will fill the gap in the literature related to determining teachers' attitudes towards distance education.

\section{Acknowledgements}

This article was produced from a master's thesis.

This research did not receive any specific grant from funding agencies in the public commercial, or not-for-profit sectors.

The authors declare no competing interests.

\section{References}

Abu Talib, M., Bettayeb, A. M., \& Omer, R. I. (2021). Analytical study on the impact of technology in higher education during the age of COVID-19: Systematic literature review. Education and Information Technologies. https://doi.org/10.1007/s10639-021-10507-1

Affouneh, S., Salha, S., \& Khlaif, Z. N. (2020). Designing quality e-learning environments for emergency remote teaching in Coronavirus crisis. Interdisciplinary Journal of Virtual Learning in Medical Sciences, 11(2), 1-3. https://doi.org/10.30476/ijvlms.2020.86120.1033

Aguliera, E., \& Nightengale-Lee, B. (2020). Emergency remote teaching across urban and rural contexts: perspectives on educational equity. Information and Learning Science, 121(5-6), 461-468. https://doi.org/10.1108/ILS-04-2020-0100

Ağır, F. (2007). Özel Okullarda Ve Devlet Okullarında Çalışan Ilköğretïm Öğretmenlerinin Uzaktan Ĕgitìme Karşı Tutumlarının Belïrlenmesi: http://dspace.balikesir.edu.tr/xmlui/bitstream/handle/20.500.12462/1591/Fatma_A _̆gr.pdf ?sequence $=1 \&$ isAllowed $=\mathrm{y}$.

Ali, W. (2020). Online and remote learning in higher education institutes: A necessity in light of COVID-19 pandemic. Higher Education Studies, 1O(3), 16. https://doi.org/10.5539/hes.v10n3p16

Alipio, M. (2020). Education during COVID-19 era: Are learners in a less-economically developed country ready for e-learning? SSRN Electronic Journal. https://doi.org/10.2139/ssrn.3586311

Anderson, T., \& Dron, J. (2011). Three generations of distance education pedagogy. International Review of Research in Open and Distance Learning, 12(3), 80-97. https://doi.org/10.19173/irrodl.v12i3.890

Arslan, R., Bircan, H., \& Eleroğlu, H., (2019). Uzaktan Eğitime Yönelik Tutum Ölçeğinin Geliştirilmesi: Cumhuriyet Üniversitesi Örneği. S.C.Ü. İktisadi ve İdari Bilimler Dergisi, 2O(2), 409-427. https://dergipark.org.tr/en/pub/cumuiibf/issue/50375/530503.

Asgharnezhad, M., Joukar, F., Naghipour, M., Nikbakht, H. A., Hassanipour, S., Arab-Zozani, M., \& Mansour-Ghanaei, F. (2020). Exploratory factor analysis of gender-based metabolic syndrome components: Results from the PERSIAN Guilan cohort study (PGCS). Clinical Nutrition ESPEN, 4O, 252-256. https://doi.org/10.1016/j.clnesp.2020.09.011 
Aydın, R., \& Sağlam, G. (2012). Öğretmen adaylarının öğretmenlik mesleğine yönelik tutumlarının belirlenmesi (Mehmet Akif Ersoy Üniversitesi Örneği). Türk Eğitim Bilimleri Dergisi, 1O(2), 257-294. https://dergipark.org.tr/en/pub/tebd/issue/26137/275280

Ayyıldız, S. Ü., Günlük, M., \& Erbey, S. N. (2006). Muhasebe Öğretim Elemanlarının Uzaktan Eğitim ve Uzaktan Muhasebe Eğitimine Yönelik Tutumları Üzerine Bir Araştırma. Muhasebe ve Finansman Dergisi, 32, 1-14. https://dergipark.org.tr/en/pub/mufad/issue/35601/395453

Bakioğlu, B., \& Çevik, M. (2020). COVID-19 Pandemisi Sürecinde Fen Bilimleri Öğretmenlerinin Uzaktan Eğitime İlişkin Görüsşleri. Journal of Turkish Studies, 15(4), 109-129. https://doi.org/10.7827/turkishstudies.43502

Başaran, M., Doğan, E., Karaoğlu, E., \& Şahin, E. (2020). Koronavirüs (COVID-19) Pandemi Sürecinin Getirisi Olan Uzaktan Eğitimin Etkililiği Üzerine Bir Çalışma. Academia Eğitim Araştırmaları Dergisi, 5(2), 368-397.

Bay, E., Vural, O., Demir, S., \& Bağceci, B. (2015). An analysis of the candidate teachers' beliefs related to knowledge, learning and teaching. International Education Studies, 8(6), 75-79. https://doi.org/10.5539/ies.v8n6p75

Belay, D. G. (2020). COVID-19, Distance learning and educational inequality in rural Ethiopia. Pedagogical Research, 5(4). https://doi.org/10.29333/pr/9133

Bozkurt, A. (2020). Koronavirüs (COVID-19) pandemi süreci ve pandemi sonrası dünyada eğitime yönelik değerlendirmeler: Yeni normal ve yeni eğitim paradigması. Açıöğretim Uygulamaları ve Araştırmaları Dergisi, 6(3), 112-142. https://dergipark.org.tr/en/pub/auad/issue/56247/773769.

Bozkurt, A., \& Sharma, R. C. (2020a). Education in normal, new normal, and next normal: Observations from the past, insights from the present and projections for the future. Asian Journal of Distance Education, 15(2), i-x. https://www.asianjde.org/ojs/index.php/AsianJDE/article/view/512.

Bozkurt, A., \& Sharma, R. C. (2020b). Emergency remote teaching in a time of global crisis due to CoronaVirus pandemic. Asian Journal of Distance Education, 15(1), 2020. https://doi.org/10.5281/zenodo.3778083

Cahapay, M. B. (2020). Reshaping assessment practices in a Philippine teacher education institution during the Coronavirus disease 2019 Crisis. Pedagogical Research, 5(4). https://doi.org/10.29333/pr/8535

Carter, R. A., Rice, M., Yang, S., \& Jackson, H. A. (2020). Self-regulated learning in online learning environments: Strategies for remote learning. Information and Learning Science, 121(5-6), 311-319. https://doi.org/10.1108/ILS-04-2020-0114

Child, D. (2006) The essentials of factor analysis. $3^{\text {rd }}$ Edition, Continuum, London.

Comrey, A. L., \& Lee, H. B., (1992), A first course in factor analysis. Hillsdale, New Jersey: Erlbaum.

Çelik, B., \& Uzunboylu, H. (2020). Developing an attitude scale towards distance learning. Behaviour \& Information Technology. Published online. https://doi.org/10.1080/0144929X.2020.1832576

Deng, M., Wang, S., Guan, W., \& Wang, Y. (2017). The development and initial validation of a questionnaire of inclusive teachers' competency for meeting special educational needs in regular classrooms in China. International Journal of Inclusive Education, 21(4), 416-427. https://doi.org/10.1080/13603116.2016.1197326

Durak, G., Çankaya, S., \& İzmirli, S. (2020). Examining the Turkish universities' distance education systems during the COVID-19 pandemic. Necatibey Eğitim Fakültesi Elektronik Fen ve Matematik Ĕ̆itimi Dergisi (EFMED), 14(1), 787-809. https://doi.org/10.17522/balikesirnef.743080 
S. Deniz \& B. Bağçeci - Development of Distance Education Attitude Scale for Teachers: ...

Edwards, J. R., \& Bagozzi, R. P. (2000). On the nature and direction of relationships between constructs and measures. Psychological Methods, 5(2), 155-174. https://doi.org/10.1037/1082989X.5.2.155

Erden, M. (1995). Öğretmen adaylarının öğretmenlik sertifikası derslerine yönelik tutumları. Hacettepe Üniversitesi Eğitim Fakültesi Dergisi, 11(11), 99-104.

Eygü, H., \& Karaman, S. (2015). Uzaktan Eğitim Öğrencilerinin Memnuniyet Algıları Üzerine Bir Araştırma. Kırıkkale Üniversitesi Sosyal Bilimler Dergisi, 3(1), 36-59. Retrieved from https://dergipark.org.tr/tr/pub/kusbd/issue/19375/205547.

Fabrigar, L. R., Wegener, D. T., MacCallum, R. C., \& Strahan, E. J. (1999). Evaluating the use of exploratory factor analysis in psychological research. Psychological Methods, 4(3), 272-299. https://doi.org/10.1037/1082-989X.4.3.272

Fernando, M. R., \& Schleicher, A. (2020). A framework to guide an education response to the COVID-19 Pandemic of 2020. OECD, 1-40.

Gardner, R. C. (1985). Social psychology and second language learning: The role of attitudes and motivation. Arnold.

Hodges, C. B., Moore, S., Lockee, B., Trust, T., \& Bond, A. (2020). The difference between emergency remote teaching and online learning. EDUCAUSE Review. https://er.educause.edu/articles/2020/3/the-difference-between-emergency-remoteteaching-and-online-learning.

Jackson, D. L., Gillaspy, J. A., \& Purc-Stephenson, R. (2009). Reporting practices in confirmatory factor analysis: An overview and some recommendations. Psychological Methods, 14, 6-23. http://dx.doi.org/10.1037/a0014694

Kahramanoğlu, R., Yokuş, E., Cücük, E., Vural, S., \& Şiraz, F. (2018). Öğretmenlik Mesleğine Yönelik Tutum Ölçeği (ÖMYTÖ) Geçerlik ve Güvenirlik Çalışması. Turkish Studies Educational Sciences, 13(11), 1669-1686. http://dx.doi.org/10.7827/TurkishStudies.13561

Kline, R. B. (2011). Methodology in the Social Sciences. Principles and practice of structural equation modelling ( $3^{\text {rd }}$ ed.). Guilford Press.

Kumari, S., \& Sood, V. (2018). Attitude of college students towards open and distance education. Conflux Journal of Education, 5(12), 2-7.

Lall, S., \& Singh, N. (2020). COVID-19: Unmasking the new face of education. International Journal of Research in Pharmaceutical Sciences, 11(Special Issue 1), 48-53. https://doi.org/10.26452/ijrps.v11iSPL1.2122

Lau, J., Yang, B., \& Dasgupta, R. (2020). Will the coronavirus make online education go viral? Retrieved from https://www.timeshighereducation.com/features/will-coronavirus-make-onlineeducation-go-viral

Lavrakas, P. J. (2008) Encyclopedia of survey research methods. Sage Publications, Inc., Thousand Oaks.

Mahmoud Raba, A. (2016). Students' attitude towards distance learning at Al-Quds Open University/ Tulkarem Educational Region. International Journal of Science and Research (IJSR), 5, 11571164.

Milman, N. (2020). This is emergency remote teaching, not just online teaching. Education Week, available at: $\quad$ www.edweek.org/ew/articles/2020/03/30/this-is-emergency-remote-teaching-notjust.html?cmp=SOC-SHR-FB (accessed 14 Dec. 2020).

Miltiadou, M., \& Yu, C. H. (1999). Validation of the online technologies self-efficacy scale (OTSES). ERIC Document Reproduction Service No: ED445672, 480, 1-17. http://creativewisdom.com/pub/efficacy.pdf.

Nunnally, J. C. (1978). Psychometric theory. $2^{\text {nd }}$ Edition, McGraw-Hill, New York. 
Perreault, H. et al. (2002). Overcoming barriers to successful delivery of distance courses. Journal of Education for Business, 77(6), 313-318. https://doi.org/10.1080/08832320209599681

Polit, D. F., Tatano Beck, C., \& Owen, S. V. (2007). Is the CVI an acceptable indicator of content validity? Appraisal and recommendations. Research in Nursing \& Health, 30(4), 459-467. https://doi.org/10.1002/nur.20199

Sanders, D. W., \& Morrison-Shetlar, A. I. (2001). Student attitudes toward web-enhanced instruction in an introductory biology course. Journal of Research on Computing in Education, 33(3), 251-262. https://doi.org/10.1080/08886504.2001.10782313

Tabata, L. N., \& Johnsrud, L. K. (2008). The impact of faculty attitudes toward technology, distance education, and innovation. Research in Higher Education, 49(7), 625-646. https://doi.org/10.1007/s11162-008-9094-7

Taber, K. S. (2018). The use of Cronbach's Alpha when developing and reporting research instruments in science education. Res Sci Edu, 48, 1273-1296. https://doi.org/10.1007/s11165-016-9602-2

Tavşancıl, E. (2002). Tutumların ölçülmesi ve SPSS ile veri analizi. Ankara: Nobel Yayın Dağıtım.

Tezbaşaran, A. (2008). Likert Tipi Ölçek Hazırlama Kılavuzu Likert Tipi Ölçek Hazırlama Kılavuzu. Ankara: Türk Psikologlar Derneği Yayınları. ISBN: 975-9756-08-5

Tzivinikou, S., Charitaki, G., \& Kagkara, D. (2020). Distance education attitudes (DEAS) during COVID-19 crisis: Factor structure, reliability and construct validity of the brief DEA Scale in Greekspeaking SEND teachers. Technology, Knowledge and Learning. https://doi.org/10.1007/s10758-020-09483-1

UNESCO (2020). UNESCO COVID-19 education response. In UNESCO, United Nations Educational, Scientific and Cultural Organization. https://resourcecentre.savethechildren.net/node/17506/pdf/75890.pdf.

Watkins, M. W. (2018). Exploratory factor analysis: A guide to best practice. Journal of Black Psychology, 44(3), 219-246. https://doi.org/10.1177/0095798418771807

Williams, B., Onsman, A., \& Brown, T. (2010). Australian paramedic graduate attributes: A pilot study using exploratory factor analysis. Emergency Medicine Journal, 27, 794-799. https://doi.org/10.1136/emj.2010.091751

Worthington, R. L., \& Whittaker, T. A. (2006). Scale development research: A content analysis and recommendations for best practices. The Counseling Psychologist, 34(6), 806-838. https://doi.org/10.1177/0011000006288127

Yamamoto, G. T., \& Altun, D. (2020). Coronavirüs ve Çevrimiçi (Online) Eğitimin Önlenemeyen Yükselişi. Üniversite Araştırmaları Dergisi, 3(1), 25-34. https://doi.org/10.26701/uad.711110

Yıldırım, K. (2020). İstisnai Bir Uzaktan Eğitim-Öğretim. Eğitim Bilimleri Eleştirel İnceleme Dergisi, 1(1), 7-15. https://doi.org/10.22596/cresjournal.0101.7.16

Yusoff, Muhamad Saiful Bahri (2019). ABC of content validation and content validity index calculation. Education in Medicine Journal, 11(2), 49-54. https://doi.org/10.21315/eimj2019.11.2.6

Zhao, Y. (2020). COVID-19 as a catalyst for educational change. Prospects, 49(1-2), 29-33. https://doi.org/10.1007/s11125-020-09477-y 
S. Deniz \& B. Bağçeci - Development of Distance Education Attitude Scale for Teachers: ...

C O A S 